\title{
PROBLEMATIKA KEPASTIAN HUKUM PERSYARATAN PENDAFTARAN PASANGAN CALON DALAM PENYELENGGARAAN PEMILIHAN KEPALA DAERAH
}

\author{
(Analisis Kasus Dugaan Pelanggaran Kode Etik Pemilihan Kepala Daerah di \\ Kabupaten Nias Utara) \\ Tengku Erwinsyahbana \\ e-mail: erwin6768@gmail.com \\ HP: 081397622420 \\ Fakultas Hukum Universitas Muhammadiyah Sumatera Utara \\ Tim Pemeriksa Daerah Pelanggaran Kode Etik Penyelenggara Pemilu \\ Propinsi Sumatera Utara
}

\begin{abstract}
ABSTRAK
Pilkada langsung secara serentak dilaksanakan pada tanggal 9 Desember 2015 hampir di seluruh wilayah Negara Kesatuan Republik Indonesia (NKRI), tetapi masih menimbulkan berbagai permasalahan, yang diasumsikan karena berbagai faktor, antara lain terkait faktor peraturan perundang-undangan dalam bidang kepemiluan. Sebagai contoh yang dapat diambil terkait dengan syarat pendaftaran pasangan calon Kepala Daerah, sebagaimana diatur dalam Pasal 45 ayat (1) dan ayat (2) d UU No. 8 Tahun 2015. Akibat ketentuan tersebut, Komisi Pemilihan Umum (KPU) dan Panitia Pengawas Pemilihan (Panwas) Kabupaten Nias Utara telah diadukan ke Dewan Kehormatan Penyelenggara Pemilu (DKPP), karena dianggap melanggar etika penyelenggaraan Pilkada. Hal ini menarik untuk dianalisis, dengan tujuan untuk mendeskripsikan problematika kepastian hukum persyaratan pendaftaran pasangan calon kepala daerah dalam sistem hukum Pemilu di Indonesia. Berdasarkan hasil analisis dapat diketahui bahwa syarat pendaftaran pasangan calon kepala daerah sebagaimana diatur dalam Pasal 45 ayat (2) d UU No. 8 Tahun 2015 belum menjamin adanya kepastian hukum dalam penyelenggaraan Pilkada, sehingga perlu direvisi kembali.
\end{abstract}

Kata Kunci: Persyaratan Pendaftaran, Pasangan Calon, Pilkada

\section{A. Latar Belakang}

Pemilihan umum atau yang disingkat dengan istilah "Pemilu", pada dasarnya merupakan kegiatan guna melaksanakan pemilihan seseorang atau beberapa orang, untuk dapat menduduki jabatan tertentu. Berdasarkan Pasal 1 angka 1 Undang-undang Nomor 8 Tahun 2012 tentang Pemilihan Umum Anggota 
Dewan Perwakilan Rakyat, Dewan Perwakilan Daerah, dan Dewan Perwakilan Rakyat Daerah (UU No. 8 Tahun 2012), ditegaskan bahwa: "Pemilihan umum, selanjutnya disebut Pemilu, adalah sarana pelaksanaan kedaulatan rakyat yang dilaksanakan secara langsung, umum, bebas, rahasia, jujur, dan adil dalam Negara Kesatuan Republik Indonesia berdasarkan Pancasila dan Undang-Undang Dasar Negara Republik Indonesia Tahun 1945 (UUDNRI 1945)”.

Pasca reformasi yang diikuti dengan amandemen UUDNRI 1945, pemilihan umum diselenggarakan untuk memilih anggota Dewan Perwakilan Rakyat, Dewan Perwakilan Daerah, Presiden dan Wakil Presiden dan Dewan Perwakilan Rakyat Daerah, dan sejak tahun 2004 penyelenggaraan Pemilu Presiden dan Wakil Presiden dilaksanakan secara langsung. Hal ini pula yang mengilhami dilaksanakannya pemilihan Kepala Daerah dan Wakil Kepala Daerah (Pilkada) secara langsung. Pilkada langsung ini, tentunya didukung pula dengan semangat otonomi daerah yang telah digulirkan sejak tahun 1999, dan oleh sebab itu, sejak tahun 2005, telah diselenggarakan Pilkada langsung, baik di tingkat propinsi, maupun kabupaten/kota, dan mulai tahun 2015 Pilkada langsung ini diselenggarakan secara serentak di berbagai daerah di Indonesia

Pasca reformasi, otonomi daerah mulai dikembangkan dan pemilihan kepala daerah yang selama masa Orde Baru ditentukan oleh anggota Dewan Perwakilan Rakyat Daerah (DPRD), mengalami perubahan, karena pada masa sekarang kepala daerah dipilih langsung oleh rakyat daerah. Berlakunya Pilkada secara langsung saat ini, lahir dari keinginan agar kepala daerah yang terpilih benar-benar representatif, artinya kepada daerah yang terpilih nantinya tidak 
merupakan hasil rekayasa politik DPRD atau benar-benar terpilih karena adanya keinginan dari rakyat di daerah.

Praktik Pilkada sekarang ini menunjukkan bahwa hukum positif dalam sistem hukum ketatanegaran telah mengalami perubahan, dan perubahan ini menunjukkan bahwa perubahan hukum tidak harus lahir dari keinginan penguasa negara, tetapi dapat juga karena adanya kehendak (keinginan) dari aspirasi rakyat yang berkembang. Dapat dikatakan bahwa semangat pembangunan hukum di Indonesia telah mengalami kemajuan pesat, yang tidak hanya ditentukan dari keinginan Pemerintah Pusat, tetapi juga didasarkan pada kebutuhan masyarakat dan atas kehendak dari rakyat di daerah.

Dilihat dari substansi hukumnya, maka aturan hukum tentang pelaksanaan Pilkada secara langsung ini telah beberapa kali mengalami perubahan, karena fakta yang terjadi menunjukkan bahwa pelaksanaan Pilkada langsung masih banyak menimbulkan berbagai persoalan. Mengingat permasalahan yang terjadi, maka pada akhirnya Pemerintah mengeluarkan Undang-undang Nomor 8 Tahun 2015 tentang Perubahan Atas Undang-undang Nomor 1 Tahun 2015 tentang Penetapan Peraturan Pemerintah Pengganti Undang-undang Nomor 1 Tahun 2014 tentang Pemilihan Gubernur, Bupati, dan Walikota Menjadi Undang-undang (UU No. 8 Tahun 2015), tetapi tidak berarti bahwa substansi undang-undang ini telah sempurna, maksudnya bahwa undang-undang ini juga masih perlu dicermati kembali.

Sesuai UU No. 8 Tahun 2015, maka pada tanggal 9 Desember 2015 telah dilaksanakan Pilkada langsung secara serentak hampir di seluruh wilayah Negara 
Kesatuan Republik Indonesia (NKRI), demikian pula di Propinsi Sumatera Utara diselenggarakan pula Pilkada langsung secara serentak untuk 21 kabupaten/kota, yaitu: Kota Medan, Kabupaten Serdang Bedagai, Kabupaten Tapanuli Selatan, Kabupaten Toba Samosir, Kota Binjai, Kabupaten Labuhan Batu, Kabupaten Asahan, Kota Sibolga, Kabupaten Pakpak Bharat, Kabupaten Humbang Hasundutan, Kabupaten Samosir, Kabupaten Labuhanbatu Utara, Kabupaten Mandailing Natal, Kabupaten Karo, Kota Tanjung Balai, Kabupaten Nias, Kabupaten Nias Selatan, Kabupaten Labuhan Batu Selatan, Kabupaten Nias Utara, Kabupaten Nias Barat dan Kota Gunung Sitoli.

Pelaksanaan Pilkada langsung secara serentak, ternyata masih menimbulkan berbagai permasalahan, yang diasumsikan karena berbagai faktor, antara lain terkait faktor peraturan perundang-undangan dalam bidang kepemiluan yang belum menjamin adanya kepastian hukum penyelenggaraan Pilkada. Sebagai contoh yang dapat diambil adalah terkait dengan syarat pendaftaran pasangan calon Kepala Daerah, sebagaimana diatur dalam Pasal 45 ayat (1) jo ayat (2) d UU No. 8 Tahun 2015, yang menentukan bahwa pendaftaran pasangan Calon Gubernur dan Calon Wakil Gubernur, pasangan Calon Bupati dan Calon Wakil Bupati, serta pasangan Calon Walikota dan Calon Wakil Walikota disertai dengan penyampaian kelengkapan dokumen persyaratan, antara lain meliputi surat keterangan tidak sedang memiliki tanggungan utang secara perseorangan dan/atau secara badan hukum yang menjadi tanggungjawabnya yang merugikan keuangan negara, dari Pengadilan Negeri yang wilayah hukumnya meliputi tempat tinggal calon. 
Ketentuan sebagaimana tersebut di atas, telah menimbulkan kerancuan hukum yang juga menyebabkan terjadinya permasalahan hukum dalam bidang kepemiluan. Contoh kasusnya telah terjadi pada penyelenggaraan Pilkada di Kabupaten Nias Utara, yang menyebabkan Komisi Pemilihan Umum (KPU) dan Panitia Pengawas Pemilihan (Panwas) Kabupaten Nias Utara diadukan ke Dewan Kehormatan Penyelenggara Pemilu Republik Indonesia (DKPP-RI), karena dianggap telah melanggar etika penyelenggaraan Pilkada. Kenyataan ini menarik diteliti dan dianalisis, sehingga diperoleh jawaban bagi upaya pembaharuan hukum guna mewujudkan sistem pemilu ideal di Indonesia, khususnya terkait dengan aturan hukum penyelenggaraan pemilihan kepala daerah di wilayah Negara Kesatuan Republik Indonesia (NKRI).

Berdasarkan latar belakang yang diuraikan di atas, maka ruang lingkup tulisan ini dibatasi hanya untuk menelaah ketentuan yang terkait dengan persyaratan pendaftaran pasangan calon Kepala Daerah, sebagaimana diatur dalam Pasal 45 ayat (2) d UU No. 8 Tahun 2015, dan masalah yang dianalisis terkait dengan kepastian hukum persyaratan pendaftaran pasangan calon kepala daerah dalam sistem hukum pemilihan kepala daerah di Indonesia.

\section{B. Kepastian Hukum dalam Perspektif Teori}

Menurut Soetandyo bahwa perkembangan hukum nasional di berbagai negara, berlangsung seiring dengan perkembangan kekuasaan negara-negara, karena yang disebut hukum nasional itu pada hakekatnya adalah hukum yang keabsahan pembentukan dan pelaksanaannya bersumber dari kekuasaan dan 
kewibawaan negara, dan ketika kehidupan berkembang ke dalam skala-skala yang lebih luas, dari lingkar-lingkar kehidupan komunitas lokal (old societies) ke lingkar-lingkar besar yang bersifat translokal pada tataran kehidupan berbangsa yang diorganisasikan sebagai suatu komunitas politik yang disebut negara yang modern (new nation state), kebutuhan akan suatu sistem hukum yang satu dan pasti (positif) sangat terasa. Sehubungan hal ini, maka gerakan ke arah unifikasi dan kodifikasi hukum terlihat marak, seolah-olah menjadi bagian inheren dari proses nasionalisasi, negaranisasi, serta modernisasi, sehingga mengakibatkan terjadinya pengingkaran eksistensi apapun yang berbau lokal dan tradisional. ${ }^{1}$

Sistem hukum di Indonesia merupakan hal yang telah menjadi wacana berkelanjutan, yang tidak hanya melibatkan para ahli dan pemerhati hukum, tetapi juga telah menarik berbagai kalangan untuk ikut menyampaikan pendapat. Fakta ini kiranya dapat dimengerti, karena dalam kenyataannya hampir tidak ada celah kehidupan yang tidak diintervensi norma hukum. Suatu adagium yang menyebutkan "di mana ada masyarakat di situ ada hukum" (ubi sociates ibi ius), menegaskan bahwa dalam kehidupan masyarakat yang paling sederhana sekalipun keberadaan norma hukum sebagai suatu pranata sosial secara nyata telah menjadi qonditio sine quanon bagi keberlangsungan hidup masyarakat sebagai suatu entitas. Beranjak dari adagium "ubi sociates ibi ius", maka Lili Rasjidi mengatakan bahwa hukum adalah sebagai sarana pengaturan yang dibuat oleh masyarakat dan diberlakukan bagi masyarakat pembuatnya, sehingga benarlah

\footnotetext{
${ }^{1}$ Soetandyo Wignjosoebroto. 2006. "Masalah Pluralisme dalam Pemikiran dan Kebijakan Perkembangan Hukum Nasional (Pengalaman Indonesia)". Makalah. Disampaikan pada acara Seminar Nasional Pluralisme Hukum Pluralisme Hukum: Perkembangan di Beberapa Negara, Sejarah Pemikirannya di Indonesia dan Pergulatannya dalam Gerakan Pembaharuan Hukum, Jakarta: Universitas Al Azhar. Hlm. 1.
} 
bahwa suatu sistem hukum adalah bermula dari masyarakat dan berakhir pada masyarakat pembentuknya, di mana hukum itu akan diterapkan. ${ }^{2}$

Pertanyaan mendasar tentang keberadaan hukum di masyarakat, selalu terkait dengan bangunan hukum dalam suatu sistem dan hal ini tentunya diperlukan untuk menjamin terciptanya kepastian hukum itu sendiri dalam kehidupan sosial masyarakat. Persoalan kepastian hukum masih menjadi hambatan dalam kegiatan penyelenggaraan negara dan pembangunan. Hal ini terjadi karena peraturan perundang-undangan yang masih tumpang tindih, tidak konsisten, tidak jelas atau multitafsir.

Berbicara tentang kepastian hukum, maka hal ini tidak dapat dilihat hanya dari aspek sosiologis, melainkan harus dianalisis secara normatif dengan cara menganalisis suatu produk perundang-undangan, baik dalam hal kesesuaiannya dengan asas-asas hukum yang berlaku umum dan cita hukum yang merupakan norma fundamental negara, maupun kesesuaiannya dalam hirarki peraturan perundang-undangan atau singkronisasi antara peraturan yang satu dengan peraturan lainnya pada tingkat vertikal dan horizontal. Kepastian hukum secara normatif umumnya dilihat dari keberlakukan peraturan yang dibuat dan diundangkan secara pasti karena mengatur secara jelas dan logis. Jelas dalam pengertian tidak menimbulkan keragu-raguan atau multitafsir, dan logis dalam pengertian menjadi suatu sistem norma yang tidak saling berbenturan atau menimbulkan konflik norma.

${ }^{2}$ Lili Rasjidi. 2008. "Pembangunan Sistem Hukum dalam Rangka Pembinaan Hukum Nasional," dalam Butir-butir Pemikiran dalam Hukum: Memperingati 70 Tahun Prof. Dr. B. Arief Sidharta, SH. Penyunting Sri Rahayu Oktoberina dan Niken Savitri. Cetakan Pertama. Bandung: Refika Aditama, Hlm. 144. 
Banyak aspek yang terkait dengan kehidupan masyarakat telah diwujudkan dalam bentuk undang-undang demi menjamin terciptanya kepastian hukum, tetapi faktanya walaupun diwujudkan dalam bentuk undang-undang, ternyata dalam pengimplementasinya tidak dipatuhi. Salah satu faktor tidak dipatuhinya undang-undang, karena dianggap bertentangan dengan perasaan keadilan ataupun cita-cita hukum masyakat, dan oleh sebab itu guna mewujudkan kepastian hukum tidaklah dapat dilakukan hanya dengan membentuknya dalam undang-undang. Hal terpenting yang juga perlu diperhatikan adalah terkait dengan cita-cita hukum masyarakat, karena apabila cita-cita hukum ini diabaikan dalam pembentukan peraturan perundang-undangan, justru dapat menyebabkan ketidakpastian hukum.

Terhadap istilah kepastian hukum, menurut Sudikno adalah perlindungan yustisiabel terhadap tindakan sewenang-wenang yang berarti bahwa seseorang akan dapat memperoleh sesuatu yang diharapkan dalam keadaan tertentu, ${ }^{3}$ sedangkan menurut Pusat Bahasa Departemen Pendidikan Nasional, disebutkan bahwa kepastian hukum adalah perangkat hukum suatu negara yang mampu menjamin hak dan kewajiban setiap warga negara. ${ }^{4}$ Pandangan lain menurut Budiono Kusumohamidjojo membedakan antara: (a) kepastian dalam orientasi bagi masyarakat (orientierungssicherbeit/certitudo); dan (b) kepastian dalam penetapan hukum oleh penegak hukum (realisierungssicherbeir/securitas). ${ }^{5}$

\footnotetext{
${ }^{3}$ Sudikno Mertokusumo. 1993. Bab-bab tentang Penemuan Hukum, Bandung: Citra Aditya Bakti. Hlm. 1.

${ }^{4}$ Pusat Bahasa Departemen Pendidikan Nasional. 2002. Kamus Besar Bahasa Indonesia, Jakarta: Balai Pustaka. Hlm. 835.

${ }^{5}$ Budiono Kusumohamidjojo. 1999. Ketertiban yang Adil (Problematik Filsafat Hukum), Jakarta: Grasindo. Hlm. 153.
} 
Demikian juga Reinhold Zippelius sebagaimana dikutip Franz Magnis Suseno, juga membedakan kepastian hukum dalam 2 (dua) pengertian, yaitu: ${ }^{6}$

1. Kepastian dalam pelaksanaannya, maksudnya bahwa hukum yang resmi diundangkan dilaksanakan dengan pasti oleh negara. Setiap orang dapat menuntut agar hukum dilaksanakan dan tuntutan itu pasti dipenuhi dan setiap pelanggaran hukum akan ditindak dan dikenakan sanksi menurut hukum juga.

2. Kepastian orientasi, maksudnya bahwa hukum itu harus jelas, sehingga masyarakat dan hakim dapat berpedoman padanya. Hal ini berarti bahwa setiap istilah dalam hukum harus dirumuskan dengan terang dan tegas sehingga tak ada keragu-raguan tentang tindakan apa yang dimaksud. Begitu pula aturan-aturan hukum harus dirumuskan dengan ketat dan sempit agar keputusan dalam perkara pengadilan tidak dapat menurut tafsiran subyektif dan selera pribadi hakim. Kepastian orientasi menuntut agar ada prosedur pembuatan dan peresmian hukum yang jelas dan dapat diketahui umum. Kepastian orientasi ini juga menuntut agar hukum dikembangkan secara kontinu dan taat asas. Undang-undang harus saling kait mengkait, harus menunjuk ke satu arah agar masyarakat dapat membuat rencana ke masa depan, begitu pula jangan dibuat undang-undang yang saling bertentangan.

Kepastian hukum harus ada dalam negara hukum, karena pada prinsipnya bahwa negara hukum mencakup 4 (empat) tuntutan dasar, yakni: (1) kepastian hukum; (2) hukum berlaku sama bagi seluruh penduduk; (3) adanya legitimasi demokratis dalam pembuatan hukum; serta (4) menjunjung tinggi martabat manusia. ${ }^{7}$ Hans Kelsen dalam pandangannya mengatakan bahwa konsep rule of law (negara hukum) yang berarti penegakan hukum, maka: (1) hukum ditegakkan demi kepastian hukum; (2) hukum itu dijadikan sumber utama bagi hakim dalam memutuskan perkara; (3) hukum tidak didasarkan pada kebijaksanaan dalam pelaksanaannya; dan (4) hukum itu harus bersifat dogmatik. ${ }^{8}$

Menurut Jimly Ashiddiqie bahwa dalam hukum harus ada keadilan dan kepastian hukum. Kepastian hukum itu penting agar orang tidak bingung, tetapi

\footnotetext{
${ }^{6}$ Franz Magnis Suseno. 2001. Etika Politik, Jakarta: Gramedia Pustaka Utama. Hlm. 79.

${ }^{7}$ Arif Hidayat. "Kepastian Hukum Harus Sejalan dengan Rasa Keadilan" dalam Antara News. http://www.antaranews.com. diakses tanggal 12 Maret 2016.

${ }^{8}$ Astim Riyanto. 2002. Filsafat Hukum. Bandung: Yapemdo. Hlm. 377.
} 
keadilan dan kepastian hukum itu sendiri merupakan dua sisi dari satu mata uang. Antara keadilan dan kepastian hukum tidak perlu dipertentangkan. Kalimatnya tidak boleh dipotong, berarti keadilan pasti identik dengan kepastian yang adil. Kalau ketidakpastian itu terjadi, berarti terjadi ketidakadilan bagi banyak orang. Jangan karena ingin mewujudkan keadilan bagi satu orang, tapi justru menciptakan ketidakadilan bagi banyak orang. Selain harus ada kepastian hukum, tujuan hukum adalah untuk mewujudkan keadilan dan keteraturan. Keadilan, kepastian hukum, dan keteraturan itu harus diwujudkan secara simultan agar tercipta kedamaian hidup bersama. $^{9}$

\section{Kasus Dugaan Pelanggaran Etika Pilkada di Kabupaten Nias Utara}

Sesuai dengan dugaan pelanggaran kode etik Pilkada yang diadukan oleh Edward Zega dan Yostinus Hulu melalui kuasa hukumnya Yosua Lase (selanjutnya disebut Pengadu) kepada DKPP-RI, dalam perkara Nomor: 04/DKPP-PKEV/2016, terkait dengan pokok pengaduan bahwa Marselinus Ingati Nazara tidak memenuhi syarat sebagai calon Bupati Nias Utara. Pengaduan ini diawali oleh peristiwa sebagai berikut:

1. Marselinus Ingati Nazara pada masa masih menjadi anggota DPRD Kabupaten

Nias Utara mempunyai pinjaman pada Bank Sumut Cabang Pembantu (Capem) Lotu, dan jaminannya adalah SK Anggota DPRD, dengan jangka waktu kredit tanggal 19-12-2014 s.d. dengan 19-04-2019.

9 Jimly Ashiddiqie. "Keadilan, Kepastian Hukum dan Keteraturan." http://www. suarakarya-online.com. diakses tanggal 12 Maret 2016. 
2. Tanggal 20-07-2015, Marselinus Ingati Nazara dengan Pdt. Herman Baeha, M.Th., mengadakan perjanjian melalui Surat Pernyataan/Perjanjian Bersama, yang isinya menyatakan bahwa utang Marselinus Ingati Nazara pada Bank Sumut Capem Lotu akan diteruskan pembayarannya oleh Pdt. Herman Baeha, M.Th, yang diikuti dengan pemberian uang secara tunai oleh Marselinus Ingati Nazara kepada Pdt. Herman Baeha, M.Th, sebagai ganti pembayaran sisa utang pada Bank Sumut Capem Lotu.

3. Surat Pernyataan/Perjanjian Bersama tanggal 20-7-2015 sebagaimana tersebut pada sub b di atas, dipertegas dengan Surat Pernyataan/Perjanjian Bersama tanggal 29-10-2015, (isinya menerangkan hal yang sama dengan perjanjian sebelumnya), tetapi surat yang kedua ini ditandatangani oleh Ketua dan Sekretaris DPRD Kabupaten Nias Utara, serta Pimpinan Bank Sumut Capem Lotu.

4. Tanggal 24-07-2015, Pengadilan Negeri Gunung Sitoli, mengeluarkan Surat Keterangan Tidak Memiliki Tanggungan Utang Nomor: W2.U12/115/SK/ HN.01.10/VII/2015, yang menerangkan bahwa Marselinus Ingati Nazara tidak memiliki tanggungan utang.

5. Tanggal 02-12-2015, Pimpinan Bank Sumut Cabang Gunung Sitoli mengeluarkan Surat Keterangan Nomor: 890/KC07-PM/L/2015 dan Pimpinan Bank Sumut Capem Lotu mengeluarkan Surat Nomor: 2506/KC07KCP085/L/2015, pada pokoknya menerangkan bahwa Marselinus Ingati Nazara masih terikat perikatan hukum terkait pinjaman pada Bank Sumut Capem Lotu. 
6. Tanggal 04-12-2015, Pengadilan Negeri Gunung Sitoli mengeluarkan Surat Nomor: W2/U12/1598/HK.02.02/XII/2015, yang pada pokoknya membatalkan Surat Nomor: W2.U12/115/SK/HN.01.10/VII/2015, seperti tersebut pada sub c di atas.

Terkait dengan rangkaian peristiwa yang dipaparkan pada sub a sampai f di atas, maka Pengadu merasa keberatan dengan lolosnya Marselinus Ingati Nazara sebagai salah satu Pasangan Calon Bupati Nias Utara, karena tidak terpenuhinya persyaratan sebagaimana dimaksud Pasal 45 ayat (2) d UU No. 8 Tahun 2015, dan oleh sebab itu Pengadu telah menyampaikan pernyataan keberatannya kepada KPU dan Panwas Kabupaten Nias Utara, yang meloloskan Marselinus Ingati Nazara sebagai Pasangan Calon Bupati Nias Utara, melalui Surat Nomor: 002/TIM-AH/PASLON-1/NU/XII/2015, tanggal 6 Desember 2015. Tanggal 12 Desember 2015, Pengadu kembali menyampaikan surat kepada KPU dan Panwas Kabupaten Nias Utara, dengan Nomor Nomor: 003/TIMAH/PASLON-1/NU/XII/2015, yang meminta agar proses penyelenggaraan Pilkada Kabupaten Nias Utara ditunda, karena tidak sesuai ketentuan hukum dan peraturan perundang-undangan yang berlaku dalam bidang kepemiluan.

Menyikapi kedua surat yang disampaikan tersebut, maka KPU dan Panwas Kabupaten Nias Utara, telah melakukan rapat pleno, tetapi dari hasil rapat diputuskan bahwa Marselinus Ingati Nazara tetap diloloskan sebagai Pasangan Calon Kepala Daerah Kabupaten Nias Utara dan tetap berhak mengikuti Pilkada. Oleh sebab itu, Pengadu melapor kepada DKPP-RI, yang isi pokok aduannya mengatakan bahwa KPU dan Panwas Kabupaten Nias Utara telah melakukan 
pelanggaran kode etik Pilkada di Kabupaten Nias Utara, karena telah meloloskan Pasangan Calon Kepala Daerah yang tidak memenuhi persyaratan pendaftaran.

\section{Problematika Kepastian Hukum Persyaratan Pendaftaran Pasangan Calon Kepala Daerah}

Berdasarkan kronologis kasus yang telah diuraikan di atas, dapat diketahui bahwa perjanjian kredit antara Marselinus Ingati Nazara dengan Bank Sumut Capem Lotu, diatur dalam lapangan hukum perdata (hukum privat), dan sesuai dengan Surat Pernyataan/Perjanjian Bersama antara Marselinus Ingati Nazara dengan Pdt. Herman Baeha, M.Th, tertanggal 20-07-2015 dan tertanggal 29-102015, dapat diketahui bahwa perikatan (dalam hal ini perjanjian kredit atau hutang piutang) antara Marselinus Ingati Nazara dengan Bank Sumut Capem Lotu telah hapus (putus).

Memperhatikan ketentuan yang terdapat dalam Pasal 1381 Kitab Undangundang Hukum Perdata (KUHPerdata), ada beberapa hal yang menyebabkan putusnya perikatan, yaitu: pembayaran, penawaran pembayaran tunai yang diikuti dengan penyimpanan atau penitipan, pembaruan utang, perjumpaan utang atau kompensasi, pencampuran utang, pembebasan utang, musnahnya barang yang terutang, dan kebatalan atau pembatalan.

Terkait dengan pembaruan utang, maka dalam Pasal 1413 KUHPerdata ditegaskan ada 3 (tiga) macam jalan untuk pembaruan utang, yaitu:

1. bila seorang debitur membuat suatu perikatan utang baru untuk kepentingan kreditur yang menggantikan utang lama, yang dihapuskan karenanya; 
2. bila seorang debitur baru ditunjuk untuk menggantikan debitur lama, yang oleh kreditur dibebaskan dan perikatannya; dan

3. bila sebagai akibat suatu persetujuan baru seorang kreditur baru ditunjuk untuk menggantikan kreditur lama, yang terhadapnya debitur dibebaskan dan perikatannya.

Memperhatikan kedua ketentuan di atas, dapat dikatakan bahwa dalam perspektif hukum perdata, Pernyataan/Perjanjian Bersama antara Marselinus Ingati Nazara dengan Pdt. Herman Baeha, M.Th, tertanggal 20-07-2015 dan tertanggal 29-10-2015, telah menyebabkan putusnya perikatan antara Marselinus Ingati Nazara dengan Bank Sumut Capem Lotu, yang didasarkan pada Pasal 1381 jo Pasal 1413 KUHPerdata. Dengan kata lain, Marselinus Ingati Nazara tidak lagi mempunyai hutang pada Bank Sumut Capem Lotu, berhubung telah ditunjuknya Pdt. Herman Baeha, M.Th sebagai debitur baru dalam perjanjian tersebut.

Adanya Surat Nomor: 2506/KC07-KCP085/L/2015, yang dikeluarkan Pimpinan Bank Sumut Capem Lotu, tidak dapat dipertanggungjawabkan secara hukum, karena sebelumnya sudah ada Surat Pernyataan/Perjanjian Bersama antara Marselinus Ingati Nazara dengan Pdt. Herman Baeha, M.Th, tertanggal 29-102015 yang juga ditandatangani oleh Pimpinan Bank Sumut Capem Lotu, dan hal ini justru menunjukkan ketidakkonsistenan dan ketidakprofesionalan Pimpinan Bank Sumut Capem Lotu. Demikian pula halnya dengan Surat Pengadilan Negeri Gunung Sitoli Nomor: W2/U12/ 1598/HK.02.02/XII/ 2015, yang pada pokoknya membatalkan Surat Nomor: W2.U12/115/SK/HN.01.10/VII/2015, tidak dapat dipertanggungjawabkan, karena hanya didasarkan pada, Surat Keterangan 
Pimpinan Bank Sumut Cabang Gunung Sitoli Nomor: 890/KC07-Pm/L/2015, tanggal 02-12-2015 dan Surat Keterangan Pimpinan Bank Sumut Capem Lotu Nomor: 2506/KC07-KCP085/L/2015, tanpa didasarkan pada Surat Pernyataan/ Perjanjian Bersama antara Marselinus Ingati Nazara dengan Pdt. Herman Baeha, M.Th., tertanggal 20-07-2015 dan 29-10-2015.

Terkait dengan persyaratan pendaftaran pasangan calon Kepala Daerah yang tertuang dalam Pasal 45 ayat (2) d UU No. 8 Tahun 2015, bahwa pendaftaran pasangan Calon Gubernur dan Calon Wakil Gubernur, pasangan Calon Bupati dan Calon Wakil Bupati, serta pasangan Calon Walikota dan Calon Wakil Walikota disertai dengan penyampaian kelengkapan dokumen persyaratan, antara lain meliputi surat keterangan tidak sedang memiliki tanggungan utang secara perseorangan dan/atau secara badan hukum yang menjadi tanggungjawabnya yang merugikan keuangan negara, dari Pengadilan Negeri yang wilayah hukumnya meliputi tempat tinggal calon, sebagai bukti pemenuhan syarat calon, juga menimbulkan kerancuan hukum atau dengan kata lain menimbulkan ketidakpastian hukum.

Sebagaimana yang ditentukan bahwa surat keterangan tidak sedang memiliki hutang tersebut dikeluarkan oleh Pengadilan Negeri yang wilayah hukumnya meliputi tempat tinggal calon. Permasalahannya bahwa untuk mengetahui informasi seseorang mempunyai hutang atau tidak, seharusnya diperoleh dari Bank Indonesia (tidak dari Pengadilan), karena pada Bank Indonesia tersedia Biro Informasi Kredit, yang melalui Biro ini dapat diperoleh informasi tentang keberadaan hutang (kredit) seseorang pada lembaga perbankan. 
Tugas utama Biro Informasi Kredit adalah menghimpun dan menyimpan data penyediaan dana/pembiayaan, dan pada akhirnya mendistribusikannya sebagai informasi kredit yang selanjutnya disebut dengan Informasi Debitur Individual (IDI) Historis. IDI Historis dapat dimanfaatkan oleh lembaga keuangan anggota Biro Informasi Kredit (perbankan dan Lembaga Keuangan Non Bank), serta masyarakat baik perorangan maupun badan usaha. Bagi lembaga keuangan, IDI Historis yang diperoleh diharapkan dapat dimanfaatkan antara lain untuk mengetahui kredibilitas (kelayakan) calon penerima fasilitas penyediaan dana (debitur) dan untuk mengetahui calon debitur dimaksud sedang menerima fasilitas penyediaan dana dari lembaga lain atau tidak. Informasi tersebut akan membantu lembaga keuangan untuk: ${ }^{10}$

1. Mempermudah analisa untuk pemberian kredit/pembiayaan, sehingga dapat memperlancar proses penyediaan dana; dan

2. Penerapan manajemen risiko antara lain untuk menghindari kegagalan membayar pinjaman yang telah diberikan dan mencegah penipuan.

Mengingat adanya Biro Informasi Kredit pada Bank Indonesia, maka sudah semestinya keterangan atau informasi tentang hutang seseorang pada lembaga keuangan (bank), tidak dikeluarkan oleh Pengadilan Negeri wilayah hukumnya meliputi tempat tinggal calon.

Permasalahan lain dalam Pasal 45 ayat (2) d UU No. 8 Tahun 2015, adalah terkait kalimat "tidak sedang memiliki tanggungan utang secara perseorangan dan/atau secara badan hukum yang menjadi tanggungjawabnya yang merugikan

\footnotetext{
${ }^{10}$ Bank Indonesia. "Biro Informasi Kredit". http://www.bi.go.id. diakses tanggal 12 Maret 2016.
} 
keuangan negara”, yang sifatnya sangat abstrak, dan dalam UU No. 8 Tahun 2015, tidak satu pasal pun yang memberikan penjelasan tentang hutang yang berpotensi merugikan keuangan Negara. Terkait kasus hutang Marselinus Ingati Nazara pada Bank Sumut Capem Lotu, tidak dapat dikatakan sebagai hutang yang berpotensi merugikan keuangan Negara, karena perjanjian pelunasan hutang tersebut telah dialihkan kepada Pdt. Herman Baeha, M.Th., dan sejak saat itu pula kewajiban melunasi hutang dimaksud beralih kepada Pdt. Herman Baeha, M.Th.

Berdasarkan uraian di atas, dapat dikatakan bahwa ketentuan yang terdapat dalam Pasal 45 ayat (2) d UU No. 8 Tahun 2015, telah menimbulkan ketidakpastian hukum, khususnya terkait dengan persyaratan pendaftaran pasangan calon Kepala Daerah. Ketidakpastian hukum ini terjadi karena ketidakjelasan substansi peraturan perundang-undangan, atau yang menurut Reinhold Zippelius dilihat dari isi orientasi. Akibat tidak adanya kepastian hukum dari sisi orientasi, dapat dipastikan akan menimbulkan ketidakpastian dalam pelaksanaan (implementasi) hukumnya, dan jika memperhatikan pendapat Budiono Kusumohamidjojo seperti yang diuraikan sebelumnya, maka hukum harus menjamin kepastian dalam orientasi bagi masyarakat, serta kepastian dalam penetapan hukum oleh penegak hukum, jika substansi hukum tidak jelas, tentu akan menimbulkan ketidakpastian dalam pelaksanannya.

Akibat ketidakpastian hukum sebagaimana yang terdapat dalam Pasal 45 ayat (2) d UU No. 8 Tahun 2015, tentunya akan berujung pada terlanggarnya nilai-nilai keadilan, karena berdasarkan Pasal 1381 jo. Pasal 1413 KUHPerdata, terlihat jelas bahwa hutang Marselinus Ingati Nazara pada Bank Sumut Capem 
Lotu telah terhapus. Hal ini sesuai dengan pendapat Jimly Ashiddiqie yang diuraikan sebelumnya, bahwa jika ketidakpastian itu terjadi, berarti terjadi ketidakadilan bagi banyak orang.

\section{E. Simpulan dan Saran}

\section{Simpulan}

Berdasarkan hasil pembahasan yang diuraikan di atas, dapat disimpulkan bahwa ketentuan tentang persyaratan pendaftaran pasangan calon dalam penyelenggaraan Pilkada sebagaimana diatur dalam Pasal 45 ayat (2) d UU No. 8 Tahun 2015, telah menimbulkan ketidakpastian hukum dalam pelaksanaan Pilkada di Indonesia.

\section{Saran}

Mengingat bahwa Pasal 45 ayat (2) d UU No. 8 Tahun 2015, telah menimbulkan ketidakpastian hukum dalam sistem hukum Pemilu di Indonesia, maka pemerintah hendaknya segera merevisi ketentuan tersebut yang merumuskan bahwa surat keterangan tidak memiliki tanggungan hutang dikeluarkan oleh Bank Indonesia, dan memformulasi ukuran secara tegas tentang jenis hutang yang berpotensi merugikan keuangan Negara. 


\section{DAFTAR PUSTAKA}

\section{Buku:}

Astim Riyanto. 2002. Filsafat Hukum. Bandung: Yapemdo.

Budiono Kusumohamidjojo. 1999. Ketertiban yang Adil (Problematik Filsafat Hukum), Jakarta: Grasindo.

Franz Magnis Suseno. 2001. Etika Politik, Jakarta: Gramedia Pustaka Utama.

Lili Rasjidi. 2008. "Pembangunan Sistem Hukum dalam Rangka Pembinaan Hukum Nasional," dalam Butir-butir Pemikiran dalam Hukum: Memperingati 70 Tahun Prof. Dr. B. Arief Sidharta, SH. Penyunting Sri Rahayu Oktoberina dan Niken Savitri. Cetakan Pertama. Bandung: Refika Aditama.

Sudikno Mertokusumo. 1993. Bab-bab tentang Penemuan Hukum, Bandung: Citra Aditya Bakti.

\section{Kamus:}

Pusat Bahasa Departemen Pendidikan Nasional. 2002. Kamus Besar Bahasa Indonesia, Jakarta: Balai Pustaka.

\section{Makalah:}

Soetandyo Wignjosoebroto. 2006. "Masalah Pluralisme dalam Pemikiran dan Kebijakan Perkembangan Hukum Nasional (Pengalaman Indonesia)". Makalah. Disampaikan pada acara Seminar Nasional Pluralisme Hukum Pluralisme Hukum: Perkembangan di Beberapa Negara, Sejarah Pemikirannya di Indonesia dan Pergulatannya dalam Gerakan Pembaharuan Hukum, Jakarta: Universitas Al Azhar.

\section{Situs Internet:}

Arif Hidayat. "Kepastian Hukum Harus Sejalan dengan Rasa Keadilan" dalam Antara News. http://www.antaranews.com. diakses tanggal 12 Maret 2016.

Bank Indonesia. "Biro Informasi Kredit". http://www.bi.go.id. diakses tanggal 12 Maret 2016.

Jimly Ashiddiqie. "Keadilan, Kepastian Hukum dan Keteraturan." http://www. suarakarya-online.com. diakses tanggal 12 Maret 2016. 


\section{Peraturan Perundang-undangan:}

Republik Indonesia, Undang Undang Dasar Negara Republik Indonesia 1945.

Republik Indonesia, Undang-undang Nomor 8 Tahun 2012 tentang Pemilihan Umum Anggota Dewan Perwakilan Rakyat, Dewan Perwakilan Daerah, dan Dewan Perwakilan Rakyat Daerah.

Republik Indonesia, Undang-undang Nomor 8 Tahun 2015 tentang Perubahan Atas Undang-undang Nomor 1 Tahun 2015 tentang Penetapan Peraturan Pemerintah Pengganti Undang-undang Nomor 1 Tahun 2014 tentang Pemilihan Gubernur, Bupati, dan Walikota Menjadi Undang-undang. 


\section{BIOGRAFI PENULIS}

Penulis adalah Dosen Kopertis Wilayah I (SUMUT) yang dipekerjakan pada Fakultas Hukum Universitas Muhammadiyah Sumatera Utara. Pendidikan S1 pada Fakultas Hukum Universitas Andalas di Padang tamat tahun 1993, Pendidikan S2 pada Program Magister Ilmu Hukum Pascasarjana Universitas Sumatera Utara di Medan tamat tahun 2006, dan Pendidikan S3 pada Program Doktor Ilmu Hukum Pascasarjana Universitas Padjadjaran di Bandung tamat tahun 2012. Bidang keahlian adalah Hukum Perkawinan, dan mulai bertugas sebagai dosen pada tahun 1994. Selain sebagai dosen, Penulis juga bertugas sebagai Tim Pemeriksa Daerah Pelanggaran Kode Etik Penyelenggara Pemilu DKPP sejak tahun 2014. 